\title{
Microhabitats occupied by Myxomycetes in the Brazilian Atlantic Forest: Heliconiaceae inflorescences
}

\author{
L. H. Cavalcanti ${ }^{a, b *}$, I. N. Ferreira ${ }^{a}$, A. C. C. Bezerra ${ }^{a}$ and A. A. A. Costa ${ }^{a}$ \\ a'Laboratório de Myxomycetes, Departamento de Botânica, Centro de Ciências Biológicas, Universidade Federal de \\ Pernambuco - UFPE, Av. Prof. Moraes Rego, s/n, Cidade Universitária, CEP 50670-971, Recife, PE, Brazil \\ bPrograma de Pós-graduação em Biologia de Fungos, Departamento de Micologia, Centro de Ciências Biológicas, \\ Universidade Federal de Pernambuco - UFPE, Av. Prof. Moraes Rego, s/n, \\ Cidade Universitária, CEP 50670-971, Recife, PE, Brazil \\ *e-mail: laise@pq.cnpq.br
}

Received: February 19, 2014 - Accepted: May 27, 2014 - Distributed: November 30, 2015

(With 2 figures)

\begin{abstract}
The occurrence of Myxomycetes in Heliconia psittacorum L.f. inflorescences was researched within four conservation units located in Northeast Brazil, aiming at evaluating the occupation of this microhabitat in fragments of Atlantic Forest along an altitude between 30-750 m. Inflorescences attached to the plant were examined; dead flowers and bracts were collected to assemble moist chambers (368). Four families, four genera and 10 species were recorded. A preference was evidenced for a basic $\mathrm{pH}$ substrate and a predominance of calcareous species (5:1). The composition of the myxobiota in fragments pertaining to altitudes above $400 \mathrm{~m}$ was similar and differed significantly from the one found in fragments of lowland forests $(<100 \mathrm{~m})$. Physarum compressum and Arcyria cinerea are the most characteristic species of the studied myxobiota.
\end{abstract}

Keywords: biodiversity, floricolous, Heliconia, myxobiota, tropical forests.

\section{Microhabitats ocupados por Myxomycetes na Floresta Atlântica Brasileira: inflorescências de Heliconiaceae}

\section{Resumo}

A ocorrência de mixomicetos em inflorescências de Heliconia psittacorum L.f. foi pesquisada em quatro unidades de conservação situadas no Nordeste do Brasil, visando avaliar a ocupação deste microhabitat em fragmentos de Floresta Atlântica, numa faixa altitudinal de 30-750 m. Foram examinadas partes mortas de inflorescências ainda presas à planta; flores e brácteas mortas foram colhidas para montagem de câmaras-úmidas (368). Foram registrados quatro famílias, quatro gêneros e 10 espécies. Evidenciou-se preferência para substrato com pH básico e predominância de espécies calcárias (5:1). A composição da mixobiota nos fragmentos de altitudes acima de $400 \mathrm{~m}$ foi semelhante e diferiu significativamente da encontrada nos fragmentos de florestas de terras baixas $(<100 \mathrm{~m})$. Physarum compressum e Arcyria cinerea são as espécies mais características da mixobiota estudada.

Palavras-chave: biodiversidade, florícola, Heliconia, mixobiota, florestas tropicais.

\section{Introduction}

Myxomycetes are common inhabitants of several types of ecosystems, often developing on dead tree trunks and branches, litter and on the barks of living trees, microhabitats explored in almost every study published on the diversity of these microorganisms. Different types of aerial litter, such as dead leaves attached to tree branches and dead flowers retained in inflorescences still attached to the mother plant, are microhabitats that are also occupied by Myxomycetes in Neotropical rainforests (Bezerra et al., 2007; Costa et al., 2009; Ferreira and Cavalcanti, 2010; Maimoni-Rodella and Cavalcanti, 2006; Schnittler

and Stephenson, 2000). Researching the occurrence of Myxomycetes in different types of microhabitats in Costa Rica, Puerto Rico and Ecuador rainforests, Schnittler and Stephenson (2002) proposed the term floricolous to characterize those species that occurred more frequently on dead floral parts protected by still living inflorescence bracts of large herbs, such as those belonging to the Costaceae, Heliconiaceae, Maranthaceae and Zingiberaceae families, of the Zingiberales order.

In Brazil, information on the occurrence of Myxomycetes in inflorescences is scarce and dispersed in the literature 
(Cavalcanti and Mobin, 2004; Ferreira and Cavalcanti, 2010; Hochgesand and Gottsberger, 1996; Silva and Cavalcanti, 2010), and only Maimoni-Rodella and Cavalcanti (2006) deal specifically with the subject, recording the occurrence of five species in living plants of Hedychium coronarium J. König (Zingiberaceae), in the state of São Paulo.

Heliconiaceae inflorescences are compact, large, with a slightly coarse perianth and flowers protected by large stiff bracts that enable the creation of microenvironments that hold organic debris and moisture. These characteristics, frequently associated with the presence of extrafloral nectaries that favor the development of yeasts and bacteria (Ruivo et al., 2006), and to a long flowering period, allow for the development of plasmodia and sporocarps in inflorescences that are still attached to the living plant (Schnittler and Stephenson, 2002). This family comprises only the Heliconia L. genus, where 200 species are currently accepted, of which about 40 occur in Brazil. One of the species, the Heliconia psittacorum L.f., has a discontinuous distribution pattern as it occurs in the rainforests of the Amazon region and along Brazil's Atlantic coastline (Rodal et al., 2005).

This work enlarges the knowledge on the distribution of floricolous Myxomycetes in the Neotropics, investigating the occupation of the microhabitat offered by H. psittacorum inflorescences, frequently found in fragments of the Atlantic Forest of the Pernambuco Endemism Center, in Brazil's Northeast region.

\section{Material and Methods}

\subsection{Study sites and field work}

Mata do Buraquinho (MB) - main remaining portion of the Atlantic Forest in the north of the state of Paraiba, with an area of 515 ha, of which 330 ha correspond to the Benjamin Maranhão Botanical Garden. The reserve is located in the municipality of João Pessoa ( $07^{\circ} 06^{\prime} \mathrm{S}$ and $34^{\circ} 52^{\prime}$ W), Mesoregion of Zona da Mata, Microregion of Paraiba's coastline, at an altitude of $45 \mathrm{~m}$. Annual rainfall is high $(2000 \mathrm{~mm})$, with average temperatures between $23^{\circ} \mathrm{C}$ and $29^{\circ} \mathrm{C}$. The predominant type of vegetation is of Lowland Dense Ombrophilous Forest and the families of dicotyledons that are best represented in the local flora are Annonaceae, Bignoniaceae, Caesalpiniaceae, Fabaceae, Lauraceae, Mimosaceae and Sapotaceae, with few trees reaching a height of $20 \mathrm{~m}$. Himatanthus phagedaenicus (Mart.) Woodson, Ocotea glomerata (Nees) Mez., Protium giganteum Engl., Tapirira guianensis Aubl. and Thyrsodium spruceanum Benth., stand out for the number of individuals and as main components of the forest canopy (Andrade-Lima and Rocha, 1971). The Heliconiaceae family is represented in the local flora by Heliconia psittacorum L.f. (Araujo et al., 2009).

Mata do Pau-Ferro State Park (PFSP) - covers an area of about 600 ha in the municipality of Areia $\left(6^{\circ} 58^{\prime} 12^{\prime} \mathrm{S}\right.$ and $35^{\circ}$ 42 ' $15^{\prime}$ W), Mesoregion of the Agreste, Microregion of the Brejo Paraibano; located at an altitude between 400-600 m, the average annual temperature lies around $22{ }^{\circ} \mathrm{C}$, with a high relative humidity of air ( $85 \%$ ) and annual pluviometric totals around $1400 \mathrm{~mm}$ (Mayo and Fevereiro, 1982). The Submontane Open Ombrophilous Forest is the predominant type of vegetation and in the botanical inventory made by Barbosa et al. (2004) 84 families and 309 species of angiosperms were identified, 89 of them in common with coastline jungles; Asteraceae, Convolvulaceae, Fabaceae lato sensu, Malvaceae, Rubiaceae and Solanaceae stand out for the number of species. Allophylus laevigatus Radlk, Bowdichia virgilioides Kunth, Guapira opposita (Vell.) Reitz, and Machaerium aculeatum Raddi. have higher importance values and number of individuals (Oliveira et al., 2006). The Heliconiaceae family is represented in local flora by H. psittacorum.

Dois Irmãos State Park (DISP) - located in the Metropolitan Mesoregion of Recife, municipality of Recife ( $8^{\circ} 01^{\prime} 15^{\prime}$ ' S and $34^{\circ} 56^{\prime} 30^{\prime \prime} \mathrm{W}$ ), covering an area of 387.4 ha, at an altitude between 30 and $80 \mathrm{~m}$. The dominating type of vegetation is that of a Lowland Dense Ombrophilous Forest, under a climate of the tropical rainy, warm and humid type, with average monthly temperatures above $23{ }^{\circ} \mathrm{C}$ and average rainfall of $2000 \mathrm{~mm}$ (Guedes, 1998; Souza et al., 2009). The families Anacardiaceae stand out for the number of individuals and Lauraceae by the number of species (Guedes, 1998). Among the trees, Brosimum discolor Schott, Tapirira guianensis and Thyrsodium spruceanum stand out for the number of individuals and relative density. The strong floristic similarity between the DISP and MB indicate that both areas are part of the same vegetational formation. In a study conducted on the flora of this conservation unit's underwood, the Heliconia genus is represented by a single species, $H$. psittacorum (Souza et al., 2009).

Frei Caneca Private Reserve of Natural Heritage (FCPRNH) - belonging to Usina Colônia SA, located in the Mata Mesoregion, Microregion of Mata Meridional of Pernambuco, municipality of Jaqueira ( $8^{\circ} 42^{\prime} 37^{\prime \prime} \mathrm{S}$ and $\left.35^{\circ} 50^{\prime} 01^{\prime} \mathrm{W}\right)$. Corresponds to the largest reserve of Atlantic Forest within a private area of the state of Pernambuco, with 630.42 ha, covering several fragments of Montane Dense Ombrophilous Forest, between altitudes of $500-750 \mathrm{~m}$; local climate is of the tropical, warm and humid type, with annual temperatures around $22{ }^{\circ} \mathrm{C}$ and $24{ }^{\circ} \mathrm{C}$. Individuals of $H$. psittacorum are present in the local herbaceous flora.

The methodology of observation and collection of sporocarps and substrates described by Stephenson et al. (2001) was adopted, exploring 40-meter wide transects in each locality and performing collections at $10 \mathrm{~m}$ intervals. On each occasion, the presence of Myxomycetes was researched on dead parts of inflorescences of $H$. psittacorum still attached to the mother plant and samples were collected for moist-chamber cultures.

\subsection{Cultures, species identification and herborization}

A total of 368 moist chambers were assembled, 70 of which were prepared with samples (dead flowers and bracts) from DISP, 179 with samples from FCPRNH, 36 from 
PFSP and 83 from MB, according to the availability of plants of the genus selected for study and of inflorescences to the required maturation phase. In $9 \mathrm{~cm}$ petri dishes, lined with filter paper, portions of inflorescences of the selected plants were placed and moistened with $8 \mathrm{~mL}$ of distilled water. After 24 hours of moist chamber assembly, $\mathrm{pH}$ values were taken and the excess water drained. The moist chambers were maintained under indirect natural light, at room temperature $\left(22-25^{\circ} \mathrm{C}\right)$ and examined weekly for three months; those that were positive regarding the presence of plasmodium were observed for a longer period of time, seeking sporulation (Stephenson et al., 2001).

Exsiccates that were representative of the material studied were deposited in the Myxomycete collection of the UFP Herbarium.

\subsection{Data analysis}

The myxobiota composition found in the four conservation units was compared employing the similarity index devised by Jaccard, generating a similarity dendrogram with the data obtained, adopting a simple connection method (Silva et al., 2003). Permutations were made employing the Monte Carlo permutation method, to test whether the similarity indexes obtained and, therefore the grouping, could be explained by chance (alfa employed $=0.05$ ). The occurrence of species in the conservation units was analyzed using the $G$ test and the $\mathbf{t}$ test to verify whether there was a difference in the richness and diversity of species between different study areas; the KolmogorovSmirnov test was employed to test the normality of data (Silva et al., 2003).

The following aspects were also considered: the community coefficient of the myxobiota, taxonomic diversity index, relation between calcareous species and non-calcareous species and abundance of species (Stephenson, 1988; Stephenson et al., 2001).

The distribution of species in Brazil is based on Cavalcanti (2014). The following abbreviations were employed for the Brazilian states: AC - Acre; AL-Alagoas;
AM - Amazonas; BA - Bahia; CE - Ceará; DF - Federal District; ES - Espírito Santo; MA - Maranhão; MG Minas Gerais; PA - Pará; PB - Paraíba; PE - Pernambuco; PI - Piauí; PR - Paraná; RJ - Rio de Janeiro; RN - Rio Grande do Norte; RR - Roraima; RS - Rio Grande do Sul; SC - Santa Catarina; SE - Sergipe; SP - São Paulo.

\section{Results}

The plants of $H$. psittacorum that were analyzed in the four conservation units vary between $1.0-1.6 \mathrm{~m}$ high with inflorescences measuring $20-25 \mathrm{~cm}$ in length and $20-40 \mathrm{~cm}$ in diameter, with 5 to 7 bracts distant from each other, fitting the type 1 classification adopted by Schnittler and Stephenson (2002). Differing from what was observed by the abovementioned authors, no record of the presence of sporocarps in Heliconia inflorescences was done directly in the field. Of the 105 specimens analyzed, all of which obtained in moist chambers, 89 could be identified on the species' level and the remainder exhibited sporocarps attacked by fungi or aborted.

\subsection{Arcyria cinerea (Bull.) Pers., Syn. Meth. Fung.: 84. 1801}

- Conservation units (Table 1): Mata do Buraquinho and Dois Irmãos State Park.

- Abundance (Table 1): 8 records.

- Substrate acidity (Table 2): pH 7.84 (7.01-8.73).

- Distribution in Brazil: North (AC, AM, PA, RR), Northeast (AL, BA, CE, PB, PE, PI, RN, SE), Southeast (MG, RJ, SP) and South (PR, RS, SC) regions. Found in natural environments or anthropized, dry and humid forests, in different microhabitats, predominating over decomposing wood (Hochgesand and Gottsberger, 1996).

- Comments: The majority of the specimens obtained exhibit the typical form of the species, with its white,

Table 1. Distribution of floricolous Myxomycetes, abundance and taxonomic diversity within four conservation units in the Atlantic Forest located in the states of Pernambuco and Paraíba, Northeast Brazil.

\begin{tabular}{|c|c|c|c|c|c|}
\hline \multirow[b]{2}{*}{ Species } & \multicolumn{4}{|c|}{ Conservation Unit / altitude } & \multirow[b]{2}{*}{ Abundance } \\
\hline & $\begin{array}{c}\text { Frei Caneca } \\
500-750 \mathrm{~m}\end{array}$ & $\begin{array}{l}\text { Pau Ferro } \\
400-600 \mathrm{~m}\end{array}$ & $\begin{array}{c}\text { Buraquinho } \\
45 \mathrm{~m}\end{array}$ & $\begin{array}{c}\text { Dois Irmãos } \\
30-80 \mathrm{~m} \\
\end{array}$ & \\
\hline Arcyria cinerea & - & - & + & + & Abundant \\
\hline Didymium anellus & - & - & - & + & Occasional \\
\hline Didymium iridis & + & + & - & - & Scarce \\
\hline Didymium minus & - & + & - & - & Scarce \\
\hline Physarum compressum & + & + & + & + & Abundant \\
\hline Physarum didermoides & - & - & - & + & Scarce \\
\hline Physarum melleum & - & - & - & + & Common \\
\hline Physarum sulphureum & - & - & - & + & Scarce \\
\hline Physarum sp. & - & - & - & + & Common \\
\hline Comatricha tenerrima & - & - & - & + & Common \\
\hline Taxonomic Diversity & 1.0 & 1.5 & 1.0 & 2.0 & \\
\hline
\end{tabular}

Abundant $=$ more than 7 specimens. Common $=$ between 5-7 specimens. Occasional $=3-4$ specimens. Scarce $=1-2$ specimens . 
Table 2. pH variation ranges for the cultures in which the species recorded on inflorescences of Heliconia psittacorum L. f. (Heliconiaceae, Zingiberales) sporulated.

\begin{tabular}{lccccc}
\hline \multicolumn{1}{c}{ Species } & \multicolumn{5}{c}{ pH range } \\
\cline { 2 - 6 } & $\mathbf{5 . 4 5 - 5 . 8 8}$ & $\mathbf{6 . 0 0 - 6 . 8 7}$ & $\mathbf{6 . 0 0 - 6 . 8 7}$ & $\mathbf{8 . 0 0 - 8 . 9 7}$ & $\mathbf{9 . 0 0 - 9 . 6 0}$ \\
\hline Arcyria cinérea & - & - & + & + & - \\
Didymium anellus & - & - & + & + & + \\
Didymium iridis & - & + & + & - & - \\
Didymium minus & - & - & - & + & + \\
Physarum compressum & - & - & + & - & + \\
Physarum didermoides & - & - & + & - & - \\
Physarum melleum & - & - & - & + & + \\
Physarum sulphureum & - & - & + & + \\
Physarum sp. & - & - & + & + \\
Comatricha tenerrima & - & + & + & + \\
Plasmodium & + & & + & + \\
\hline
\end{tabular}

creamy or gray, long or short cylindrical sporotheca and stalk equal or little over half the total size of the sporocarp. Farr (1976) comments that the culture in moist chambers can alter the color, the shape and the size of the sporocarps, a fact observed in some specimens of $A$. cinerea obtained from the material taken from the DISP.

\subsection{Comatricha tenerrima (M. A. Curtis) G. Lister,}

Guide Brit. Mycetozoa, ed. 4: 39. 1919

- Conservation unit (Table 1): Dois Irmãos State Park.

- Abundance (Table 1): 5 records.

- Substrate acidity (Table 2): pH 8.21 (7.00-8.97).

- Distribution in Brazil: Northeast (PE, RN), Southeast (SP) and South (PR) regions. Found in secondary forests, on dead wood, herbaceous stalks, leaves, sugarcane bagasse and palm trees (Hochgesand and Gottsberger, 1996).

- Comments: The specimens, developed in moist chamber on $H$. psittacorum flowers, exhibit a ribbonshaped pedicle varying in the shape of the sporotheca (fuse-shaped, egg-shaped and subcleaved) and in the total height of the sporocarp. Fructifications were scarce, with 1 to 7 sporocarps per specimens, hindering identification, a fact also observed by many authors that employ the moist chamber technique. This species was regarded as common due to the number of specimens obtained, however it was only recorded in Lowland Ombrophilous Forests, sporulating with a $\mathrm{pH}$ ranging from 7.0 to 8.97 .

\subsection{Didymium anellus Morgan, J. Cincinnati Soc. Nat.} Hist. 16: 148. 1864

- Conservation unit (Table 1): Dois Irmãos State Park.

- Abundance (Table 1): 4 records.
- Substrate acidity (Table 2): pH 8.30 (7.84-9.23).

- Distribution in Brazil: Northeast (PE) and Southeast (SP) regions. Found in Restinga Forests and Lowland Dense Ombrophilous Forests, over dead leaves, herbaceous stalks, thin branches, palm tree inflorescences, rare on wood (Hochgesand and Gottsberger, 1996; Silva and Cavalcanti, 2010).

- Comments: The characteristics exhibited by the four specimens analyzed fit well in the keys and descriptions by Martin and Alexopoulos (1969) and Poulain et al. (2011). This species was considered occasional in the present study, recorded only in the fragment of Lowland Dense Ombrophilous Forest located in Pernambuco.

3.4. Didymium iridis (Ditmar) Fr., Syst. Mycol. 3: 120.1829

- Conservation units (Table 1): PRNH Frei Caneca and Mata do Pau Ferro State Park.

- Abundance (Table 1): 2 records.

- Substrate acidity (Table 2): pH 6.56 (6.0 and 7.12).

- Distribution in Brazil: Northeast (BA, CE, PE, MA), Southeast (MG, RJ, SP) and South (SC) regions. Found in Submontane Dense Ombrophilous Forests, over decomposing wood, leaves, branches, moss, herbaceous stalks (Hochgesand and Gottsberger, 1996).

- Comments: In the present study, two specimens were obtained in the forest fragments located at altitudes above $400 \mathrm{~m}$ and represent the typical form of the species.

\subsection{Didymium minus (Lister) Morgan, J. Cincinnati} Soc. Nat. Hist. 16: 145.1894

- Conservation unit (Table 1): Mata do Pau Ferro State Park. 
- Abundance (Table 1): 1 record.

- Substrate acidity (Table 2): pH 7.09.

- Distribution in Brazil: North (AC, AM), Northeast (BA, PB, PE) and Southeast (SP) regions. Found in Submontane Dense Ombrophilous Forests over decomposing wood, leaves, branches, moss, herbaceous stalks (Hochgesand and Gottsberger, 1996).

- Comments: With low representativeness in the analyzed floricolous myxobiota, the only specimen obtained sporulated on material from PFSP, exhibiting the typical characteristics of the species.

\subsection{Physarum compressum Alb. \& Schwein., Consp. Fung. Lusat.: 97. 1805}

- Conservation units: PRNH Frei Caneca, Dois Irmãos State Park, Mata do Pau Ferro State Park and Mata do Buraquinho.

- Abundance (Table 1): 73 records.

- Substrate acidity (Table 2): pH 7.53 (6.48-9.23).

- Distribution in Brazil: Northeast (AL, BA, CE, PE, MA, SE), Southeast (SP) and South (PR, SC, $\mathrm{RS})$ regions. Found in Restinga Forests and in anthropized environments, on dead leaves or plant fragments, palm tree inflorescences and trunks, bromeliad inflorescences and sugarcane bagasse (Hochgesand and Gottsberger, 1996; Ferreira and Cavalcanti, 2010).

- Comments: According to Martin and Alexopoulos (1969) this species can appear in the form of a pedicellated sporangium and of a plasmodiocarp. Some of the specimens obtained in the present study were typical, while others exhibited morphology alterations of the sporotheca and stalk dimensions, attributed to the culture conditions in moist chambers.

\subsection{Physarum didermoides (Pers.) Rostaf., Sluzowce Monogr: 97. 1874}

- Conservation unit (Table 1): Dois Irmãos State Park.

- Abundance (Table 1): 1 record.

- Substrate acidity (Table 2): pH 9.11.

- Distribution in Brazil: Northeast (BA, PE), Southeast (SP) and South (SC, RS) regions. Found in the Atlantic Forest, on dead wood and dead leaves, living tree barks, sugarcane and straw (Hochgesand and Gottsberger, 1996).

- Comments: This species was absent or scarce in the conservation units studied, with just a single specimen recorded in the DISP.
3.8. Physarum melleum (Berk. \& Broome) Massee, Monogr. Myxogastr: 278. 1892

- Conservation unit (Table 1): Dois Irmãos State Park.

- Abundance (Table 1): 5 records.

- Substrate acidity (Table 2): pH 7.0 (7.1-7.73).

- Distribution in Brazil: North (AM), Northeast (AL, BA, PE, PI, RN, SE), Southeast (SP) and South $(\mathrm{PR}, \mathrm{SC})$ regions. Found in Restinga Forests and in urban environments, on dead wood and dead leaves, sugarcane bagasse, inflorescences and dead palm tree leaves (Hochgesand and Gottsberger, 1996).

- Comments: A species regarded as common in the floricolous myxobiota analyzed but recorded only on the material from DISP. The sporocarps exhibit characteristics that are typical for the species, with some specimens strongly impregnated with calcium.

\subsection{Physarum sulphureum Alb. \& Schwein., Consp. Fung. Lusat.: 93.1805}

- Conservation unit (Table 1): Dois Irmãos State Park.

- Abundance (Table 1): 1 record.

- Substrate acidity (Table 2): pH 7.73.

- Distribution in Brazil: Northeast Region (PE). Found in the Atlantic Forest, on diverse substrates of plant origin.

- Comments: Sporocarp characteristics correspond to those described by Martin and Alexopoulos (1969) for $P$. sulphureum, differing only for the absence of a calcium crust on the sporotheca.

\subsection{Physarum sp}

- Conservation unit (Table 1): Dois Irmãos State Park.

- Abundance (Table 1): 5 records.

- Substrate acidity (Table2): pH 8.45 (8.08-9.06).

- Comments: Gray colored plasmodiocarps, calcareous peridium, capillicium with calcium nodules connected by hyaline filaments; developed in moist chambers with a basic $\mathrm{pH}$, prepared with inflorescences, flowers and bracts of $H$. psittacorum from Lowland Dense Ombrophilous Forests. Identification of the species was not possible due to the conditions of its sporocarps; however, one can say that they belong to the Physarum genus, for the characteristics of their capillicium.

Considering the relation between calcareous and non-calcareous species, a proportion of 5:1 was obtained, confirming that the members of Physarales comprise the majority of the Myxomycetes associated with the analyzed microhabitat. By calculating the taxonomic diversity index 
for each site (Table 1), the values found for the floricolous myxobiota of DISP (2.0) and of PFSP (1.5), were slightly higher with regard to MB and to FCPRNH (1.0).

The presence of Myxomycetes were recorded in $51.36 \%$ of the total 368 moist chambers prepared, where in $29.35 \%$ (108 cultures) plasmodia were formed that did not reach the sporulation phase while sporulation occurred in $22.01 \%$ ( 81 cultures). A high percentage of cultures where plasmodia did not sporulate are reported by several authors, particularly in tropical rainforests, such as those studied by Schnittler and Stephenson (2000) in Costa Rica. About $80 \%$ of the cultures prepared with material from MB and DISP, lowland forests and little less than half from highland forests were positive (with plasmodium and/or sporocarp). However, when one considers the cultures that reached sporulation, the percentage was low (ca 20\%) in the cultures assembled with material from MB while almost $100 \%$ was reached in the cultures from PFSP, where the lowest variation in $\mathrm{pH}$ values occurred, around 7.0 (Figures 1 and 2).

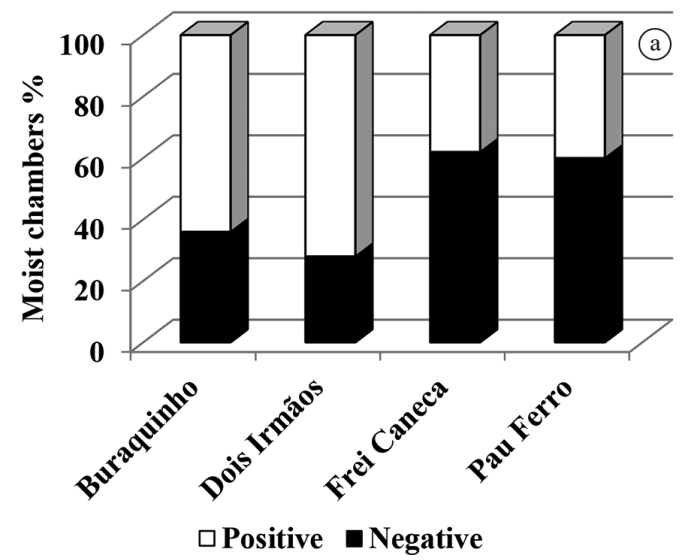

The cultures prepared with inflorescences from the conservation units of Atlantic Forest located in the states of Pernambuco and Paraíba exhibited a $\mathrm{pH}$ variation between 5.45-9.60; in the range of acid $\mathrm{pH}(5.45-5.88)$ only plasmodia developed, with no occurrence of sporulation (Table 2). Comparing the percentages of positive cultures (plasmodia and/or sporocarps) obtained in the ranges of $\mathrm{pH}$ below 7.0 with those recorded in cultures with a $\mathrm{pH}$ equal or above 8.0 , a significant preference $(\mathrm{p}<0.05)$ was found for the more alkaline environment, confirming what was considered by Schnittler and Stephenson (2002) as the preferred behavior for floricolous species. The number of positive cultures was significantly greater for those in which the culture's initial $\mathrm{pH}$ was basic $(\geq 8.0)$ with regard to the acidic $\mathrm{pH}$ (below 7.0). However, after enabling the formation of plasmodium in more acid moist chambers, the number of species (2) present in these positive cultures did not significantly differ in the number of species (8) originated in positive cultures that had a basic $\mathrm{pH}$.

Figure 1. Moist chambers cultures prepared with Heliconia psittacorum L.f. (Heliconiaceae, Zingiberales) inflorescences from four conservation units of Atlantic Forest located in the states of Pernambuco and Paraíba. (a) Percentage of positive and negative cultures; (b) Percentage of positive cultures that sporulated.

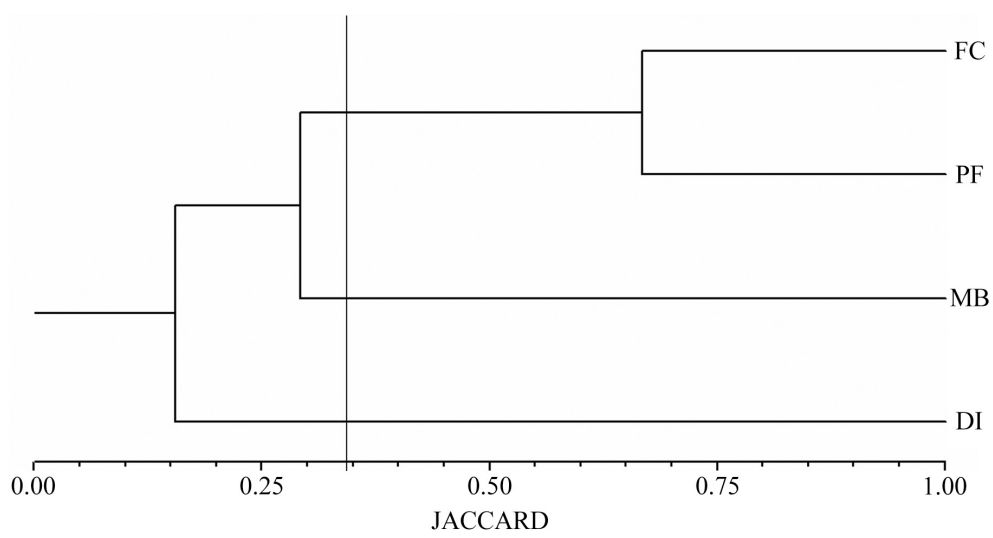

Figure 2. Composition similarity dendrogram of floricolous myxobiota found in four conservation units of the Atlantic Forest located in Pernambuco and Paraíba states, Northeast Brazil. 
Cultures prepared with inflorescences from DISP exhibited a significant difference $(\mathrm{p}<0.05)$ in $\mathrm{pH}$ values when compared to those from $\mathrm{MB}$, which could explain the difference in the number of species recorded, and with PFSP, located at a higher altitude; $\mathrm{pH}$ values of PFSP also differ significantly $(\mathrm{p}<0.05)$ from those recorded at FCPRNH, both from highlands.

$\mathrm{G}$ and $\mathbf{t}$ tests indicated that there is no significant difference when one considers the richness and diversity of the species between the four conservation units, even when DISP, located at a lower altitude, exhibited a number of species of Myxomycetes four times higher than was recorded at FCPRNH and at PFSP, both with altitudes above $400 \mathrm{~m}$.

Physarum compressum is the only species that is common to all four conservation units, MB and DISP sharing also $A$. cinerea (Table 1 ). Therefore, a low similarity was confirmed between the floricolous myxobiota in the two conservation units located at similar altitudes $(C C=0.44)$ and fitting the same type of forest (Table 3 ). A community coefficient with a similar value $(\mathrm{CC}=0.45)$ was found when the floricolous myxobiota found in all four conservation units studied were compared to the most frequent and abundant floricolous species found for Neotropical forests analyzed by Schnittler and Stephenson (2002).

Although the difference in richness found in the four locations (2-3 species in the higher altitudes) has not been statistically significant, it was clear that the composition of the myxobiota of forests located above $400 \mathrm{~m}$ is similar $(\mathrm{CC}=0.80)$ and differs from the one found in lowlands (Table 3). The dendrogram obtained confirms that the difference in similarity found among conservation units of highlands in relation to lowlands, is not explained by chance (Figure 2).

\section{Discussion}

In tropical rainforests, the group of Myxomycetes associated with inflorescences is very poor in species, with a clear predominance of Physarales and Trichiales, with few genera prevailing, highlighting Arcyria and Physarum (Schnittler and Stephenson, 2002; Stephenson et al., 2004). In the present work, four families, each represented by just one genus, were recorded in the moist chambers prepared with $H$. psittacorum inflorescences from the four conservation units of Atlantic Forest studied. Among the recorded species, $A$. cinerea and $P$. compressum stand out as the most abundant and well distributed.
Stephenson et al. (2001) comment that the S/G values found for the myxobiota of temperate and tropical areas vary between 2.2 and 4.6. These authors consider the myxobiota found in Iceland, Northern Russia, Northern Alaska and Greenland impoverished, where S/G values vary between 1.4 and 2.2. The values found for the floricolous myxobiota for each site can be considered impoverished according to the criteria established by Stephenson et al. (2001).

Physarum compressum, $P$. didermoides and P. melleum (Physaraceae) were included by Schnittler and Stephenson (2002) among the 13 most abundant floricolous species found in rainforests of Puerto Rico, Costa Rica and Ecuador, on inflorescence remains of Zingiberales of the Costaceae (Costus, 1sp.), Zingiberaceae (Hedychium, 1sp.), Marantaceae (Calathea, 3 spp.) and Heliconiaceae (Heliconia, 8 spp.) families. In the present work, $P$. compressum was the most abundant species found and the most representative in the floricolous myxobiota analyzed, as it was recorded in all forest fragments and altitudes studied. The same behavior was observed in the environments studied by Schnittler and Stephenson (2002) that reported 126 records in the field and its presence in $35.2 \%$ of the positive moist chambers; the abovementioned authors concluded that, in tropical rainforests, $P$. compressum seems to be a good indicator of basic $\mathrm{pH}$ (8.5-9.0) however, in the present work, this species sporulated in a wider $\mathrm{pH}$ range (6.48-9.23). Schnittler and Stephenson (2002) found P. melleum in remains of floral parts of Hedychium coronarium and Psychotria poeppigiana Mull. Arg. (Rutacaeae) and, based on recorded $\mathrm{pH}$ values, concluded that this species seems to be incapable of inhabiting inflorescences of Costus and Heliconia, characterized by a very basic $\mathrm{pH}$. In the present study however, $P$. melleum developed a plasmodium and sporulated on decomposing floral portions of H. psittacorum, in a $\mathrm{pH}$ range that varied between 7.0-7.73. This species is also referred to as a floricolous species by Lado et al. (2003), developed in moist chambers prepared with floral parts of Astrocaryum mexicanum Liebm. ex Mart. (Arecaceae) collected at the Tuxtlas Station, in Mexico. Physarum didermoides and P. sulphureum were scarce in the environments studied, sporulating on substrate with a basic $\mathrm{pH}$, and the latter is not among the floricolous mentioned by Schnittler and Stephenson (2002).

Didymium species correspond to almost $50 \%$ of the floricolous myxomycetes recorded in Costa Rica, Puerto Rico and Ecuador; however, the three species of the Didymiaceae family recorded in the present study were classified as occasional or scarce. Didymium anellus and

Table 3. Community coefficient between recorded floricolous myxobiota in four conservation units of the Atlantic Forest located in Pernambuco and Paraíba States Northeast Brazil.

\begin{tabular}{lcccc}
\hline & Frei Caneca & Pau Ferro & Buraquinho & Dois Irmãos \\
\hline Frei Caneca & 100 & & & \\
Pau Ferro & 0.80 & 100 & 100 & 100 \\
Buraquinho & 0.50 & 0.40 & 0.44 & 100 \\
Dois Irmãos & 0.22 & 0.20 & & \\
\hline
\end{tabular}


D. minus are not included among the floricolous species recorded in the studies conducted in Neotropical forests. In Brazil, the occurrence of $D$. anellus is known only for the state of São Paulo, where it was collected on Heliconia sp. leaves in the coastal city of São Sebastião (Hochgesand and Gottsberger, 1996), and in Pernambuco, collected on bracts and on dead inflorescences of Elaeis guineenses Jacq. (Arecaceae), on fragments of Lowland Dense Ombrophilous Forests (Silva and Cavalcanti, 2010).

The only representative of the Trichiaceae, $A$. cinerea was the second most abundant species in the present study, sporulating on the flower and bract of $H$. psittacorum, on material derived from lowland forests. It was included by Schnittler and Stephenson (2002) among the 13 floricolous species with more than five records in the studies conducted in the forests of Ecuador, sporulating on inflorescences of plants belonging to different genera of Zingiberales, with an occurrence percentage in moist chambers of $3.6 \%$ in its typical form and $8.1 \%$ in its dwarf form, and was also observed in the field (13 specimens). In Brazil, Maimoni-Rodella and Cavalcanti (2006) also include A. cinerea among the species occurring on $H$. coronarium inflorescences and Silva and Cavalcanti (2010) refer to its presence on inflorescences of E. guineensis, in a fragment of Lowland Dense Ombrophilous Forests in the Gurjaú Ecological Reserve, in Pernambuco.

Comatricha tenerrima was the only representative of the Stemonitaceae present among the 10 species found in this study, agreeing with the weak global representation of the Stemonitomycetidae subclass in this ecological group. This species was included by Schnittler and Stephenson (2002) among those that exhibited less than five records on decomposing floral parts, always with scarce sporocarps, making identification doubtful. In the present study, despite being classified as common, it was registered only in Lowland Dense Ombrophilous Forests, sporulating in a $\mathrm{pH}$ of a range of 7.0 to 8.97 .

Schnittler and Stephenson (2002) recorded an average $\mathrm{pH}$ of $8.08 \pm 0.04$ in the 358 moist chambers prepared with inflorescences and concluded that, among all the environment parameters analyzed for the floricolous group, the substrate's $\mathrm{pH}$ is one of the most important as well as the disposition of the bracts of Zingiberales' inflorescences. Two environment parameters, annual rainfall and altitude, would work in the opposite direction, while light intensity and exposure to wind were less important. However, in the present study, $\mathrm{G}$ and $\mathbf{t}$ tests indicated that the general pattern of the diminishing richness of species with the increase in altitude, reported in the studies conducted in the Neotropics by Stephenson et al. $(1999,2004)$ and Schnittler and Stephenson $(2000,2002)$, was not observed for the assemblage of Myxomycetes associated with Heliconia inflorescences, with no significant differences regarding the richness and diversity of the species that occupy this microhabitat in the four conservation units of the Atlantic Forest studied.

\section{Conclusion}

The information reported in literature and the data obtained in the present work confirm that, in rainforests, in the microcosm comprised by Heliconia inflorescences, there is a stable and specific set of Myxomycetes that develop on decomposing floral parts of the inflorescences still attached to the mother plant.

Despite offering potentially favorable conditions for the development of Myxomycetes, Heliconia inflorescences do not constitute one of the microhabitats frequently occupied in an Atlantic Forest environment.

\section{Acknowledgements}

The authors wish to thank National Council for Scientific and Technological Development-CNPq (Proc. 305967/2009-6), for the financial support given to the first author.

\section{References}

ANDRADE-LIMA, D.A. and ROCHA, M.G.L., 1971. Observações preliminares sobre a Mata do Buraquinho, João Pessoa, Paraíba. Anais do Instituto de Ciências Biológicas da UFRPE, vol. 1, pp. 47-61.

ARAÚJO, J.L.O., QUIRINO, Z.G.M., GADELHA NETO, P.C. and ARAUJO, A.C., 2009. Síndromes de polinização ocorrentes em uma área de Mata Atlântica, Paraíba, Brasil. Biotemas, vol. 22, no. 4, pp. 83-94.

BARBOSA, M.R.V., AGRA, F.M., SAMPAIO, E.V.S.B., CUNHA, J.P. and ANDRADE, L.A., 2004. Diversidade florística da Mata de Pau Ferro, Areia, Paraíba. In: K.C. PORTO, J.J.P. CABRAL and M. TABARELLI, orgs. Brejos de altitude em Pernambuco e Paraíba: história natural, ecologia e conservação. Brasília: Ministério do Meio Ambiente, pp. 111-122.

BEZERRA, A.C.C., NUNES, A.T., COSTA, A.A.A., FERREIRA, I.N., BEZERRA, M.F.A. and CAVALCANTI, L.H., 2007. Mixobiota do Parque Estadual das Dunas de Natal. Revista Brasileira de Biociências, vol. 5, no. s2, pp. 30-32.

CAVALCANTI, L.H., 2014 [viewed 12 January 2014]. Myxomycetes. In: JARDIM BOTÂNICO DO RIO DE JANEIRO. Lista de Espécies da Flora do Brasil [online]. Rio de Janeiro. Available from: http://floradobrasil.jbrj.gov.br

CAVALCANTI, L.H. and MOBIN, M., 2004. Myxomycetes associated with palm trees at the Sete Cidades National Park, Piauí State, Brazil. Systematics and Geography of Plants, vol. 74, pp. 109-127.

COSTA, A.A.A., TENÓRIO, J.C.G., FERREIRA, I.N. and CAVALCANTI, L.H., 2009. Myxomycetes de Floresta Atlântica: novas referências de Trichiales, Liceales e Stemonitales para o Estado da Paraíba, Nordeste do Brasil. Acta Botanica Brasílica, vol. 23, no. 2, pp. 313-322. http://dx.doi.org/10.1590/S010233062009000200003 .

FARR, M.L., 1976. Myxomycetes. New York: The New York Botanical Garden. Flora Neotropica Monografia, no. 16.

FERREIRA, I.N. and CAVALCANTI, L.H., 2010. Disponibilidade de microhabitats para Myxomycetes em Floresta Atlântica: Bromeliaceae. Biotemas, vol. 23, pp. 1-10. 
GUEDES, M.L.S., 1998. A vegetação fanerogâmica da Reserva Ecológica de Dois Irmãos. In: I.C. MACHADO, A.V. LOPES and K.C. PORTO, orgs. Reserva Ecológica de Dois Irmãos: estudo em um remanescente de Mata Atlântica em área urbana. Recife: Secretaria de Ciências, Tecnologia e Meio Ambiente, pp. 157-172.

HOCHGESAND, E. and GOTTSBERGER, G., 1996. Myxomycetes from the state of São Paulo, Brazil. Boletim do Instituto de Botanica, vol. 10, pp. 1-47.

LADO, C., ESTRADA-TORRES, A., STEPHENSON, S.L., BASANTA, D.W. and SCHNITTLER, M., 2003. Biodiversity assessment of myxomycetes from two tropical forest reserves in Mexico. Fungal Diversity, vol. 12, pp. 67-110.

MAIMONI-RODELLA, R.C.S. and CAVALCANTI, L.H., 2006. Myxomycetes sobre inflorescências e folhas vivas de lírio-do-brejo (Hedychium coronarium Koenig, Zingiberaceae): registro de um novo substrato. Revista Brasileira de Botanica, vol. 29, no. 2, pp. 331-333. http://dx.doi.org/10.1590/S0100-84042006000200014.

MARTIN, G.W. and ALEXOPOULOS, C.J., 1969. The Myxomycetes. Iowa: University of Iowa Press.

MAYO, S.J. and FEVEREIRO, V.P.B., 1982. Mata do Pau-Ferro: a pilot study of the brejo forest. Kew: Royal Botanic Gardens.

OLIVEIRA, F.X., ANDRADE, L.A. and FÉLIX, L.P., 2006. Comparações florísticas e estruturais entre comunidades de Floresta Ombrófila Aberta com diferentes idades, no Município de Areia, PB, Brasil. Acta Botanica Brasílica, vol. 20, no. 4, pp. 861-873. http://dx.doi.org/10.1590/S0102-33062006000400011.

POULAIN, M., MEYER, M. and BOZONNET, J., 2011. Les Myxomycètes. Sèvrier: Fédération Mycologique et Botanic Dauphiné-Savoie.

RODAL, M.J.N., SALES, M.F., SILVA, M.J. and SILVA, A.G., 2005. Flora de um brejo de altitude na escarpa oriental do planalto da Borborema, PE, Brasil. Acta Botanica Brasílica, vol. 19, no. 4, pp. 843-858. http://dx.doi.org/10.1590/S0102-33062005000400020.

RUIVO, C.C.C., LACHANCE, M.-A., ROSA, C.A., BACCI JUNIOR, M. and PAGNOCCA, F.C., 2006. Candida heliconiae sp. nov., Candida picinguabensis sp. nov. and Candida saopaulonensis sp. nov., three ascomycetous yeasts from Heliconia velloziana (Heliconiaceae). International Journal of Systematic and
Evolutionary Microbiology, vol. 56, no. 5, pp. 1147-1151. http:// dx.doi.org/10.1099/ijs.0.64097-0. PMid:16627669.

SCHNITTLER, M. and STEPHENSON, S.L., 2000. Myxomycetes biodiversity in four different forest types in Costa Rica. Mycologia, vol. 92, no. 4, pp. 626-637. http://dx.doi.org/10.2307/3761420.

SCHNITTLER, M. and STEPHENSON, S.L., 2002. Inflorescences of Neotropical herbs as a newly discovered microhabitat for myxomycetes. Mycologia, vol. 94, no. 1, pp. 6-20. http://dx.doi. org/10.2307/3761841. PMid:21156473.

SILVA, C.F. and CAVALCANTI, L.H., 2010. Myxobiota of the Brazilian Atlantic forest: species on oil palm tree (Elaeis guineensis, Arecaceae). Rodriguesia, vol. 61, pp. 575-583.

SILVA, R.A., SANTOS, A.M. and TABARELLI, M., 2003. Riqueza e diversidade de plantas lenhosas em cinco Unidades de Paisagem da Caatinga. In: I.R. LEAL, M. TABARELLI and J.M.C. SILVA, orgs. Ecologia e conservação da caatinga. Recife: Editora Universitária UFPE, pp. 337-365.

SOUZA, A.C.R., ALMEIDA JUNIOR, E.B. and ZICKEL, C.S., 2009. Riqueza de espécies de sub-bosque em um fragmento florestal urbano, Pernambuco, Brasil. Biotemas, vol. 22, pp. 57-66.

STEPHENSON, S.L., 1988. Distribution and ecology of Myxomycetes in temperate forests. I. Patterns of occurrence in the upland forests of Southwestern Virginia. Canadian Journal of Botany, vol. 66, pp. 2187-2207.

STEPHENSON, S.L., LANDOLT, J.C. and MOORE, D.L., 1999. Protostelids, dictyostelids, and myxomycetes in the litter microhabitat of the Luquillo Experimental Forest, Puerto Rico. Mycological Research, vol. 103, no. 2, pp. 209-214. http://dx.doi. org/10.1017/S0953756298006996.

STEPHENSON, S.L., NOVOZHILOV, Y.K. and SCHNITTLER, M., 2001. Distribution and ecology of myxomycetes in high-latitude regions of the Northern Hemisphere. Journal of Biogeography, vol. 27 , no. 3, pp. 741-754. http://dx.doi.org/10.1046/j.13652699.2000.00442.x.

STEPHENSON, S.L., SCHNITTLER, M., LADO, C., ESTRADATORRES, A., BASANTA, D.W., LANDOLT, J.C., NOVOZHILOV, Y.K., CLARK, J., MOORE, D.L. and SPIEGEL, F.W., 2004. Studies of neotropical mycetozoans. Systematics and Geography of Plants, vol. 74, pp. 87-108. 